\title{
Supplementation of Molasses and Branched-Chain Amino Acids to Increase In Vitro Digestibility of Ammoniated Corn Cob in Ruminants Feed
}

\author{
Puastuti $\mathrm{W}^{1}$, Yulistiani $\mathrm{D}^{1}$, Handiwirawan $\mathrm{E}^{2}$ \\ ${ }^{1}$ Indonesian Research Institue of Animal Production, PO Box 221, Bogor 16002 \\ ${ }^{2}$ Indonesian Center for Animal Research and Development, Jalan Raya Pajajaran Kav. E-59 Bogor 16151 \\ E-mail: wisri_puast@yahoo.com
}

(received: 23-10-2017; revised: 30-11-2017: accepted: 15-12-2017)

\begin{abstract}
ABSTRAK
Puastuti W, Yulistiani D, Handiwirawan E. 2017. Suplementasi molases dan asam amino bercabang pada tongkol jagung amoniasi sebagai pakan ruminansia untuk meningkatkan kecernaan in vitro. JITV 22(4): 179-187. DOI: http://dx.doi.org/10.14334/jitv.v22i4.1664

Tongkol jagung memiliki kandungan serat kasar dan lignin yang tinggi sehingga menyebabkan kecernaan nutriennya rendah. Penelitian bertujuan untuk meningkatkan kecernaan tongkol jagung (TJ) amoniasi melalui suplementasi molases dan asam amino bercabang (BCAA) valin, leusin dan isoleusin. Tongkol jagung diolah dengan penambahan urea $3 \%$. Uji in vitro tahap pertama dilakukan dengan 4 taraf molases 0, 5, 10 dan 15\% dari bahan kering (BK) TJ. Percobaan dilakukan dengan RAL 4 perlakuan yang diulang 4 kali. Uji in vitro tahap kedua, suplementasi valin $=\mathrm{V}$, leusin $=\mathrm{L}$ dan isoleusin $=\mathrm{I}$ dengan taraf masing-masing 0,1 dan $0,2 \%$ dari BK TJ amoniasi. Terdapat 8 perlakuan yaitu $\mathrm{A}=\mathrm{V} 0,1 \mathrm{~L} 0,1 \mathrm{I} 0,1 ; \mathrm{E}=\mathrm{V} 0,2 \mathrm{~L} 0,1 \mathrm{I} 0,1 ; \mathrm{B}=\mathrm{V} 0,1$ L0,1 I0,2; F = V0,2 L0,1 I0,2; C = V0,1 L0,2 I0,1; G = V0,2 L0,2 I0,1; D = V0,1 L0,2 I0,2; H = V0,2 L0,2 I0,2 dan 1 kontrol (V0,0 L0,0 I0,0). Percobaan dilakukan dengan RAL 9 perlakuan dan diulang 3 kali. Hasil percobaan menunjukkan bahwa pengolahan TJ dengan urea mampu meningkatkan kadar protein sebesar 78\% (3,34\% menjadi 5,95\%) sedangkan NDF menurun sebesar $>15,4 \%$, ADF sebesar 7,9\% dan lignin 16,7\%. Nilai kecernaan BK TJ amoniasi meningkat $(\mathrm{P}<0,05)$ sebesar 7,5\% $(41,9$ vs 43,51-46,26\%) dan NDF sebesar 17,7\% (38,41 vs 43,76-46,31\%) karena tambahan molases. Suplementasi BCAA menghasilkan kecernaan BK, BO dan NDF tertinggi $(\mathrm{P}<0,05)$ pada perlakuan A, C, D dan G. Kecernaan BK, BO dan NDF pada perlakuan $\mathrm{G}$ dibandingkan dengan I masing-masing sebesar 31,4\%, 27,5\% dan 36,5\% serta menghasilkan populasi bakteri total rumen tertinggi sebesar $12,4 \times 10^{9} \mathrm{koloni} / \mathrm{ml}$. Dapat disimpulkan bahwa kecernaan TJ amoniasi meningkat melalui suplementasi molases $5 \%$ dan kombinasi BCAA yang terdiri dari valin $0,2 \%$, leusin $0,2 \%$ dan isoleusin $0,1 \%$.
\end{abstract}

Kata Kunci: Tongkol Jagung, Amoniasi, Molases, Asam Amino Bercabang

\section{ABSTRACT}

Puastuti W, Yulistiani D, Handiwirawan E. 2017. Supplementation of molasses and branched-chain amino acid to increase in vitro digestibility of ammoniated corn cob in ruminants feed. JTV 22(4): 179-187. DOI: http://dx.doi.org/10.14334/jitv.v22i4.1664

Corn cob contains high fiber and lignin which causes low nutritive value. The objective of the study was to improve the digestibility of ammoniated corn cob (CC) by supplementation of molasses and branched-chain amino acid (BCAA: valine, leucine and isoleucine). $\mathrm{CC}$ was processed by addition 3\% urea. The first stage of in vitro test was done with 4 levels of molases $0,5,10$ and $15 \%$ of dry matter (DM) of CC. The experiment was carried out using complete randomized design with 4 treatments and 4 replications. The second stage was also in vitro study of supplementation of two levels each for valine $=\mathrm{V}$, leucine $=\mathrm{L}$ and isoleucine $=\mathrm{I}$ namely 0.1 and $0.2 \%$ of DM of ammoniated CC. There were 8 treatments combination of the BCAA as follow: A = V0.1 L0.1 I0.1; E = V0.2 L0.1 I0.1; B = V0.1 L0.1 I0.2; F = V0.2 L0.1 I0.2; C = V0.1 L0.2 I0.1; G = V0.2 L0.2 I0.1; D = V0.1 L0.2 I0.2; H = V0.2 L0.2 I0.2 and 1 control (V0.0 L0.0 I0.0). The experiments were done using completely randomized design with 9 treatments and 3 replications. The results showed that treated CC with urea was able to increase protein content by $78 \%$ (increased from $3.34 \%$ to $5.95 \%$ ) while neutral detergent fiber (NDF) decreased by $15.4 \%$, acid detergent fiber (ADF) by $7.9 \%$ and lignin $16.7 \%$. Addition of molasses in ammoniated CC increased DM digestibility (P <0.05) by $7.5 \%$ (41.9 vs 43.51-46.26\%) and NDF by $17.7 \%$ (38.41 vs $43.76-46.31 \%$ ). Supplementation of BCAA resulted in the highest DM, OM and NDF digestibility $(\mathrm{P}<0.05)$ in the treatment of $\mathrm{A}, \mathrm{C}, \mathrm{D}$ and $\mathrm{G}$. Compare to treament I, the digestibility of $\mathrm{DM}$, OM and NDF in G treatment increased by $31.4 \%, 27.5 \%$ and $36.5 \%$, respectively and produced the highest total population of rumen bacterial of $12.4 \times 10^{9}$ colonies $/ \mathrm{ml}$. It can be concluded that the digestibility of ammoniated CC increased by the supplementation of $5 \%$ molases and BCAA combination consisted of $0.2 \%$ valine, $0.2 \%$ leucine and $0.1 \%$ isoleucine.

Key Words: Corn Cob, Ammoniation, Molasses, Branched-Chain Amino Acid 


\section{INTRODUCTION}

National production of corn grain in 2017 was 27.957 million tons (Pusdatin 2017). The potential of corn cob availability calculated based on ratio of grain, straw, husk and corn cob, was 55.0, 20.312 .3 and $12.3 \%$, respectively (Yulistiani et al. 2012). Corn cob production in 2017 was 6.251 million tons. The utilization of corn cob as feed was still limited. Some of dry corn cob was used as fuel, while most leaves were piled up and rotten in the field. Corn cob had low nutrient quality due to low protein $(1.5-3.5 \%)$, high fiber $(35-45 \%)$ high lignin $(5.2 \%)$, and high cellulose $(30 \%)$ contents (Yulistiani et al. 2012; Hastuti et al. 2011). Lignin in corn cob caused low nutrient availability and low dry matter digestibility $(45.5 \%)$ and organic matter digestibility $(42.5 \%$ ) (Yulistiani et al. 2012). Lower digestibility (29.34\%) was also reported by Setyadi et al (2013).

To increase the nutrient quality of fibrous feed, many processing methods have been done such as physical, chemical and biological or combination of these methods. Those treatments were reported able to increase the utilization and digestibility of agricultural by-products feedstuff (Van Soest 2006; Zain et al. 2010; Nurhaita 2010).

Physical treatment by grinding resulted in easier feed handling and for consumption, however it did not significantly increase feed digestibility. Increasing quality of roughage was reported by using chemical treatment of sodium hyadroxide (Adeniji 2010) or urea (Oji et al. 2007; Dean et al. 2008; Yalchi et al. 2009; Puastuti et al. 2010; Yulistiani et al. 2012, Ubwa et al. 2014). Urea treatment on rice straw was able to increase nutrient content increasing animal growth through improving rice straw palatability (Huyen et al. 2012), increased nutrient digestibility in dairy cattle (Wanapat et al. 2009) and increased NDF and ADF digestibility in goat and bull (Gunun et al. 2013). The increased of nutrient content and digestibility due to urea treatment was also reported in Triticale straw (Yalchi et al. 2009), cacao pod (Puastuti et al. 2010; Laconi \& Jayanegara 2015), corn cob (Yulistiani et al. 2012), oil palm frond (Febrina 2012) and rice husk (Ubwa et al. (2014). The mechanism of urea treatment in improving nutrient content of low quality feed is through hemicellulose solubilization, swollen of plant cell wall and disruption of lignin and cellulose linkage (Yalchi et al. 2009). Consequently the digestibility of cellulose and hemicellulose was increased. This increased digestibility was not followed by the loss of lignin (Bata 2008). Differed to biological treatment, urea treatment in low quality feed is simple and applicative for small holder farmers.

The nutritive value of fibrous feed beside affected by processing method also affected by enzymatic digestion produced by rumen microbes. Various rumen microbes have important role in digesting feed in the rumen. Beside that rumen microbes also be used as protein source in ruminant. Rumen microbes at least supplied two third or $70-80 \%$ of amino acid required by ruminants (Chumpawadee et al. 2006; Pathak 2008). The higher rumen microbes population particularly cellulolytic bacteria produced more enzyme consequently increased fiber digestibility. Feeding low quality feeds with low protein and high fiber contents would limit its nutrient availability for microbial. (Puastuti 2009; Nurhaita \& Ningrat 2011).

Fermentable energy source (sugar, starch) was needed for the growth of rumen microbials. Molases was fermentable source of carbohydrate and could be used as energy source for rumen microbes (Bata 2008). Amino acid was main nitrogen source for microbial synthesis in the rumen. Although cellulolytic rumen microbial was able to use ammonia, but amino acid and protein had better advantage compared to urea for microbial synthesis (McAllen \& Smith 1983; Clark et al. 1992). High degradable protein will be fast degraded by rumen microbes in the rumen into amino acid and partly will be further degraded and produced ammonia. This ammonia is used as nitrogen source and as carbon skeleton source for rumen microbial synthesis. Therefore amino acid composition of feed protein is important for ruminant animals. Methionin, lysine, fenylalanin and threonine were amino acid needed by ruminants (Scholljegerdes et al. 2005). Other amino acid also needed by ruminants were valin, isoleusin, dan leusin (Volden 1999; Zain 2007). These three amino acids were known as branched chain amino acid (BCAA) in the rumen which would be decarboxylated and oxidative deaminated into branched-chain volatile fatty acid (BCVFA) which had important role in the activity of cellulolytic bacteria (Tedeschi et al. 2015). BCVFA could increase dry matter digestibility, increase rumen microbial growth and increase microbial function and enzyme activity in the rumen of sheep (Moharrery 2004). Considering results from the previous studies, this study was aimed to increase ammoniated corn cob digestibility through supplementation of molasses and combination of branch-chain amino acid valin, leusin, and isoleusin.

\section{MATERIALS AND METHODS}

Corn cob was obtained from Majalengka District, West Java Province. The cob was ground, then processed using ammoniation by urea addition at $3 \%$ of cob dry matter (DM) (Yulistiani et al. 2012). Corn cob and urea mixture was then kept anaerobically condition for 21 days. Ammoniated corn cob then dried and ground for chemical analysis and evaluated for its in vitro digestibility. First in vitro digestibility study was 
conducted to evaluate the requirement of energy source on the utilization of ammoniated corn cob as fiber source. Molasses supplementation as energy source was allocated in 4 levels namely $0,5,10$, dan $15 \%$ of corn cob DM. The study was conducted through randomized complete design with four replications. Substance samples were incubated for 72 hour, which was previously prepared according to the method of Menke and Steingass (1988) and digestibility was measured according to the methods of Blummel et al (1997). Rumen fluid for in vitro study was taken from ram fed on fresh chopped elephant grass, supplemented with concentrate feed containing crude protein $16 \%$. Parameter recorded were digentibility of DM, organic matter (OM) and neutral detergent fiber (NDF). The best molasses level in this in vitro digestibility was used in the second experiment in which the ammoniated corn cob and molasses mixture was supplemented by branch-chain amino acid (BCAA).

The second in vitro evaluation was carried out to study the effect of BCAA supplementation. BCAA supplemented were valin (V), leusin (L) and isoleusin (I) (L-Valine product by Himedia Laboratory Pvt., Ltd., and L-Leucine by Appli Chem). Levels of BCAA supplementation were 0.1 dan $0.2 \%$ of DM ammoniated CC. There were 8 combinations of the BCAA of treatment, which were: A (V0.1 L0.1 I0.1); B (V0.1 L0.1 I0.2); C (V0.1 L0.2 I0.1); D (V0.1 L0.2 I0.2); E (V0.2 L0.1 I0.1); F (V0.2 L0.1 I0.2); G (V0.2 L0.2 I0.1); H (V0.2 L0.2 I0.2) and I (V0.0 L0.0 I0.0). The study was conducted in randomized complete design with 9 treatments and 3 replications. The method used in vitro evaluation was similar to the first experiment. Parameter recorded were digestibility of DM, OM, and $\mathrm{NDF}$, and number of population bacteria and protozoa.

$\mathrm{DM}, \mathrm{OM}$, crude protein $(\mathrm{CP})$ and gross energy $(\mathrm{GE})$ content of the samples were analysed using method of AOAC (1990). Whereas NDF, acid detergent fiber (ADF) and lignin were analyzed according to the methods of Van Soest et al. (1991). Bacterial and protozoal population were determined using total plate count method (Ogimoto \& Imai 1981). Data obtained were analysed using analysis of variance. The difference between treatment mean were analysed using Duncan multiple range test. Statistical analysis was done using soft ware of SAS 9.0 (SAS 2002).

\section{RESULTS AND DISCUSSION}

\section{Ammoniated corn cob}

Physical condition of ammoniated corn cob was changed, after treatment and its texture was softer and had brownish color. The chemical analysis of the cob showed that ammonization increased the CP content by $78 \%$ (from 3.34 in untreated into $5.95 \%$ in urea treated corn cob). Chemical composition of untreated and urea treated corn cob are presented in Table 1. The increased of $\mathrm{CP}$ content in ammoniated corn cob was due to nitrogen fixation from urea catabolism by urease bacterial (Dean et al. 2008). The increase of CP content in this study was in agreement with the study reported by Oji et al. (2007). They reported that processing of corn by-products with $3 \%$ urea was able to increased CP content by 77\%. Yadete (2014) reported that processing of wheat straw using $4 \%$ urea was able to increased CP content by $87.5 \%$ (from $3.2 \%$ into $6.0 \%$ ).

The increase of CP content in rice husk due to urea treatment was also reported by Ubwa et al. (2014). Yulistiani et al. (2012) reported higher increased of CP content in corn cob treated with urea $3 \%$, increasing the CP content up to $284.5 \%$. While Ramirez et al. (2007) reported the CP content was increased by $125 \%$ and $270 \%$ in maize by-products with urea treatment levels of 4.5 and $6.5 \%$ respectively. The different in increase of $\mathrm{CP}$ content due to urea treatment in corn cob might be caused by the different level of urea used for treatment. Optimum level of urea in the process of ammonization was reported at the level of 3-5\% (Gunun et al. 2013; Khejornsart \& Wanapat 2010). Urea levels less than $3 \%$ only had function as preservative and it would loss as ammonia when higher than 5\% (Khejornsart \& Wanapat 2010). The length of storage (21 days) might vary the difference in CP content as the urea added was fractionating into ammonia and some evaporate during drying, so that the amount of $\mathrm{N}$ calculated as $\mathrm{CP}$ would be lower.

NDF content of ammoniated corn cob decreased by $15.5 \%$, while ADF by $7.9 \%$ and lignin by $16.7 \%$, whereas GE content decreased only by $2.5 \%$. The results of the present study was in agreement with Nurfeta et al. (2008) who reported that urea

Table 1. Nutrient composition of corn cob untreated or ammoniated corn cob

\begin{tabular}{lcccccccc}
\hline \hline Feed & DM & Protein & Ash & NDF & ADF & Lignin & GE \\
Kcal $/ \mathrm{kg}$
\end{tabular}

$\mathrm{DM}=$ Dry matter; $\mathrm{NDF}=$ Neutral detergent fiber $; \mathrm{ADF}=$ Acid detergent fiber $; \mathrm{GE}=$ Gross energy 
treatment in wheat straw reduced NDF content. Chemical treatment by urea addition cause disruption the linkage between cell wall component particularly linkage between lignin and cellulose or hemicellulose so that digestibility by enzymatic become easier. Previously Sumarsih et al. (2007); Mapato et al. (2010) stated that ammonia treatment increased digestibility by lossen lignocellulose bound consequently carbohydrate digestibility increased. Beside that urea treatment also increased feed palatability. The increase of digestibility in urea treated in rice straw caused the increase in feed consumption (Hailu et al. 2011)

\section{Effect of molasses supplementation on digestibility of ammoniated corn cob}

Different levels of molasses supplementation significantly $(\mathrm{P}<0.05)$ affected $\mathrm{DM}, \mathrm{OM}$ and $\mathrm{NDF}$ digestibility. Nutrient digestibility of ammoniated corn cob supplemented by molasses is presented in Table 2 .

Digestibility evaluation of DM, OM and NDF of ammoniated $\mathrm{CC}$ with molasses addition as energy source, was significantly different $(\mathrm{P}<0.05)$ among levels of molasses supplementation. Digestibility value of ammoniated CC supplemented by molasses presented in Table 2.

Result from Duncan analysis showed that molassess supplementation up to $5 \%$ was not able to increased DM and OM digestibility. The digestibility was increased $(\mathrm{P}<0.05)$ at 10 and $15 \%$ molasses supplementation compare to control (without molasses supplementation). The NDF digestibility was increased $(\mathrm{P}<0.05)$ at $5 \%$ molasses supplementation compared to control, but this was not significantly different from 10 and $15 \%$ supplementation. DM digestibility of $41.9 \%$ of ammoniated $\mathrm{CC}$ in this study was similar to the results reported by Prastyawan et al. (2012). Who reported that fermented ammoniated corn cob without starter microbes for 4 weeks incubation resulted in DM digestibility of $41.3 \%$. The value was higher than reported by Setyadi et al. (2013) which was $29.34 \%$.

Compared to control, the average incrase in DM digestibility due to molasses supplementation was $9.2 \%$ (41.9 vs 43.51-46.26\%), whereas the incrase in NDF digestibility was $17.7 \%$ (38.41 vs 43.76-46.31\%) (Table $2)$. The increase digestiility with the increase of urea treatment could be due to urea treatment producing nitrogen in the form of NH3. Similar results was also reported on nitrogen supplementation in rice straw which was able to improve deficiency of CP content, consequently the straw digestibility was increased due to the ammonia (NH3) availability which was needed for the activity of rumen microbial for the fermentation of feed (Wanapat et al. 2009). Microbial protein synthesis required NPN and carbohydrate source from feed (Al Qori'ah et al. 2016). Therefore, the high potential of ammonia had to be synchronized with availability of fermentable energy. Ammoniated feed which directly fed to ruminants will result in imbalanced $\mathrm{N}$ caused by high $\mathrm{N}$ degradation but lack of fermentable carbohydrate and consequently more $\mathrm{N}$ release which in turn caused low feed digestibility. Therefore this feed should be balanced with fermentable carbohydrate which will optimize rumen microbial activity. The available fermentable carbohydrate ammonia will be converted into protein microbial and stimulate multiplication of rumen microbial, which will be able to increase feed digestibility (Bata 2008).

The increase of rumen microbial population which produces more enzymes resulted in the increased feed digestibility. Therefore in the present study ammoniated corn cob as feed supplemented with fermentable carbohydrate such as molasses which was expected to be able to optimize the activity of rumen microbial through the available $\mathrm{N}$ in the form of ammonia and energy which needed for rumen microbial multiplication and optimizing microbial activity in

Table 2. Effect of molasses supplementation on nutrient digestibility of ammoniated corn cob

\begin{tabular}{|c|c|c|c|}
\hline \multirow{2}{*}{ Molasses levels } & \multicolumn{3}{|c|}{ Digestibility } \\
\hline & Dry Matter & Organic Matter & Neutral Detergent Fiber \\
\hline & & ------------------- & - \\
\hline $0 \%$ & $41.90 \pm 1.02^{\mathrm{b}}$ & $43.19 \pm 0.95^{\mathrm{b}}$ & $38.41 \pm 1.07^{\mathrm{b}}$ \\
\hline $5 \%$ & $43.51 \pm 0.77^{\mathrm{ab}}$ & $44.84 \pm 0.94^{\mathrm{ab}}$ & $43.76 \pm 1.50^{\mathrm{a}}$ \\
\hline $10 \%$ & $45.30 \pm 2.00^{\mathrm{a}}$ & $46.56 \pm 1.98^{\mathrm{a}}$ & $45.53 \pm 1.63^{\mathrm{a}}$ \\
\hline $15 \%$ & $46.26 \pm 2.57^{\mathrm{a}}$ & $47.35 \pm 2.60^{\mathrm{a}}$ & $46.31 \pm 3.35^{\mathrm{a}}$ \\
\hline
\end{tabular}

Values in same column with different superscripts indicates significantly different $(\mathrm{P}<0.05)$ 
supplementation for ruminants fed on fibrous feed with carbohydrate fermentation due to the availability of ammonia and energy for the growth of rumen microbial. Crude protein degradation in ammoniated corn cob produced intermediate products in the form of ammonia. With the availability molasses as energy source, rumen microbes will incorporate with NH3 as source of $\mathrm{N}$ for protein synthesis of the microbes, particularly cellulolytic bacteria which in turn this bacteria will digest fiber. Some of rumen microbial required $\mathrm{N}$ for microbial synthesis in the form of ammonia. Minimum concentration required was about $3.57 \mathrm{mM}$ (Satter \& Slyter 1974) or in the ranges of 3.57-7.14 $\mathrm{mM}$ that had to be produced from protein in the diet (Swandyastuti and Rimbawanto, 2015). The increase of molasses levels resulted in non-significant increase of NDF digestibility, this could be caused by excessive energy available wich was not balanced with available $\mathrm{N}$. The simultaneous available energy and nitrogen was essential to be to provide nutrient needed by rumen microbes.

In the present study, though digestibility of ammoniated CC supplemented by molasses increased in DM digestibility, but somehow still lower than of elephant grass digestibility (60.9\%) (Santoso et al. 2009). Therefore, the process of treating crn cob with urea, it had to be combined with fermentable carbohydrate supplementation to increase digestibility due to the increase rumen microbial population. Principally fiber digestibility has to be close relation to enzyme produced by rumen microbial. Basic nutrients needed for rumen microbial synthesis was available energy balanced with nitrogen in the form of ammonia. In the present study, molasses containing high glucose was added. As stated by Nurhaita et al (2014) that nutrient required for microbial protein synthesis was energy, nitrogen, mineral and amino acid in the form of BCAA. Therefore it is proper in order to increase digestibility of ammoniated $\mathrm{CC}$ can be done by supplementation of branched-chain amino acid (BCAA) to stimulate the growth of rumen microbial.

\section{Effect of BCAA supplementation on ammoniated CC}

Digestibility value of ammoniated $\mathrm{CC}$ with supplementation of 5\% molasses and BCAA is presented in Table 3. Ammoniated $\mathrm{CC}$ feed as fiber source with $5 \%$ molasses increased NDF digestibility by $13.9 \%$ (Table 2). Ammoniated CC digestibility could be increased by supplementation of branch-chain amino acid through stimulation of protein microbial synthesis. Digestibility value of ammoniated $\mathrm{CC}$ is presented in Table 3. The digestibility of DM, OM and NDF of corn cob was increased $(\mathrm{P}<0.05)$ by BCAA supplementation. The significant increase of low quality, resulted in better rumen environment for digestibility due to BCAA supplementation was in treatment A, C, D and G. The digestibility of DM, OM and NDF in ammoniated CC (Tabel 2) was improved by $35.03 \%, 33.38 \%$ and $25.42 \%$, respectively.

The results of present study supported previous research reported by Zain et al. (2008) that BCAA (valin $0,1 \%$, leusin $0,15 \%$, isoleusin $0,2 \%$ ) supplementation in palm press fiber basal ration was able to increased DM and OM digestibility by $22,84 \%$ (from 56,47 to $69,37 \%$ ) and $21,61 \%$ (from $57,84 \%$ to $70,34 \%$ ), respectively. Although DM, OM and NDF in treatment $G$ was not statistically significantly differ from treatment $\mathrm{A}, \mathrm{C}$ and $\mathrm{D}$, treatment $\mathrm{G}$ was better in term of increase total bacterial population $\left(12,4 \times 10^{9}\right.$ coloni/ml) (Table 4).

In the present study supplementation of BCAA might be used as precursor for microbial protein synthesis which was able to increase bacterial population thereby increased fiber digestibility of ammoniated CC.

Bacteria population increased more than 1.5 times compared to control. In contrast, protozoa population $(3.50 \times 105 \mathrm{cell} / \mathrm{ml})$ in BCAA supplementation was significantly lower compared to control (13.5 x 105 cell $/ \mathrm{ml}$ ). This results indicated that combination of BCAA supplementation in treatment $G$ was able to support the growth of rumen bacterial.

Branched-chain amino acid had significant role in increasing protein synthesis in human and animal (Zhang et al. 2017). Amino acid in the rumen is utilized by rumen microbes to synthesize protein microbial. Rumen bacteria, particularly cellulolytic bacteria required branched-chain fatty acid (BCFA) consisted of isobutyric, 2 metil butiryc, and valeryc acid as source bacterial carbon skeleton. This BCFA produced from decarbocilated and deaminated BCAA. Most BCAA in the rumen produced from fermentation of protein in the diet and lysis of rumen microbial (Zhang et al. 2017). With the low quality of agroindustrial by-products in term of low content in BCAA, therefore BCAA (valin, isoleucin, and leucin) supplementation in agroindustrial by-producs basal diet is needed to increase rumen microbial population and fiber digestibility.

Based on treatment of BCAA supplementation in ammoniated $\mathrm{CC}$, there was indication of negative correlation between bacterial and protozoal population in the rumen (Figure 2). This correlation follows the equation $y=-2.1338 x+27.99 ; \mathrm{R} 2=0.7756$.

Feeding diet containing high fiber such as corn cob with high bacterial population and low protozoal population (Treatment G, Table 3) will be very beneficial due to bacteria population. Fibrolytic bacteria particularly is needed to increase fiber digestibility this fiber digestibility produced energy in the form VFA which is used as energy source for ruminants. 
Table 3. Effect of combination of BCAA valin, leusin and isoleusin supplementation on ammoniated corn cob (CC) digestibility

\begin{tabular}{lccc}
\hline \hline & & Digestibility & \\
Treatments & DM & OM & NDF \\
\cline { 2 - 4 } & & $59.67 \pm 0.38^{\mathrm{a}}$ & $55.85 \pm 2.18^{\mathrm{a}}$ \\
A & $59.54 \pm 0.37^{\mathrm{a}}$ & $57.28 \pm 1.48^{\mathrm{ab}}$ & $51.84 \pm 1.31^{\mathrm{ab}}$ \\
B & $55.76 \pm 1.42^{\mathrm{ab}}$ & $60.24 \pm 1.54^{\mathrm{a}}$ & $55.19 \pm 1.37^{\mathrm{a}}$ \\
D & $58.88 \pm 1.48^{\mathrm{a}}$ & $59.84 \pm 2.41^{\mathrm{a}}$ & $54.30 \pm 2.12^{\mathrm{a}}$ \\
E & $58.51 \pm 2.3^{\mathrm{a}}$ & $54.57 \pm 0.91^{\mathrm{ab}}$ & $49.07 \pm 0.91^{\mathrm{ab}}$ \\
F & $52.85 \pm 0.60^{\mathrm{ab}}$ & $53.72 \pm 2.86^{\mathrm{ab}}$ & $47.22 \pm 2.53^{\mathrm{ab}}$ \\
G & $51.54 \pm 2.75^{\mathrm{ab}}$ & $59.49 \pm 2.35^{\mathrm{a}}$ & $54.19 \pm 1.99^{\mathrm{a}}$ \\
H & $58.06 \pm 2.19^{\mathrm{a}}$ & $53.71 \pm 3.69^{\mathrm{ab}}$ & $45.33 \pm 3.22^{\mathrm{ab}}$ \\
I & $51.10 \pm 3.51^{\mathrm{ab}}$ & $46.67 \pm 6.36^{\mathrm{b}}$ & $39.70 \pm 6.13^{\mathrm{b}}$ \\
\hline
\end{tabular}

$\mathrm{DM}=$ Dry matter; $\mathrm{OM}=$ Organic matter; $\mathrm{NDF}=$ Neutral detergent fiber

$\mathrm{A}=(\mathrm{V} 0.1, \mathrm{~L} 0.1 \mathrm{I} 0.1)$; $\mathrm{B}=(\mathrm{V} 0.1, \mathrm{~L} 0.1, \mathrm{I} 0.2) ; \mathrm{C}=(\mathrm{V} 0.1, \mathrm{~L} 0.2) ; \mathrm{D}=(\mathrm{V} 0.1, \mathrm{~L} 0.2$, I 0.2); I 0.1); E = (V 0.2, L 0.1, I 0.1)

$\mathrm{F}=(\mathrm{V} 0.2, \mathrm{~L} 0.1, \mathrm{I} 0.2) ; \mathrm{G}=(\mathrm{V} 0.2, \mathrm{~L} 0.2, \mathrm{I} 0.1) ; \mathrm{H}=(\mathrm{V} 0.2, \mathrm{~L} 0.2, \mathrm{I} 0.2) ; \mathrm{I}(\mathrm{control})=(\mathrm{V} 0.0, \mathrm{~L} 0.0, \mathrm{I} 0.0)$.

Values in same column with different superscripts indicates significantly different $(\mathrm{P}<0.05)$.

Table 4. Effect of combination of valin, leusin and isoleusin supplementation in ammoniated CC on rumen microbial population

\begin{tabular}{lcc}
\hline \hline Treatments & Bacteria $\left(10^{\wedge} 9 \mathrm{col} / \mathrm{ml}\right)$ & Protozoa $\left(10^{\wedge} 6 \mathrm{cell} / \mathrm{ml}\right)$ \\
\hline A & $2.80 \pm 0.14^{\mathrm{f}}$ & $2.58 \pm 0.12^{\mathrm{a}}$ \\
B & $6.98 \pm 0.60^{\mathrm{c}}$ & $1.70 \pm 0.10^{\mathrm{c}}$ \\
C & $3.87 \pm 0.12^{\mathrm{e}}$ & $2.23 \pm 0.03^{\mathrm{b}}$ \\
D & $6.06 \pm 0.56^{\mathrm{d}}$ & $1.27 \pm 0.11^{\mathrm{d}}$ \\
E & $7.46 \pm 0.83^{\mathrm{c}}$ & $0.85 \pm 0.15^{\mathrm{e}}$ \\
F & $10.11 \pm 0.08^{\mathrm{b}}$ & $0.55 \pm 0.05^{\mathrm{f}}$ \\
G & $12.40 \pm 1.1^{\mathrm{a}}$ & $0.50 \pm 0.05^{\mathrm{g}}$ \\
H & $7.12 \pm 0.73^{\mathrm{dc}}$ & $1.20 \pm 0.05^{\mathrm{d}}$ \\
I & $4.63 \pm 0.38^{\mathrm{e}}$ & $1.35 \pm 0.05^{\mathrm{d}}$ \\
\hline
\end{tabular}

$\mathrm{DM}=$ dry matter; $\mathrm{OM}=$ Organic matter; $\mathrm{NDF}=$ Neutral detergent fiber,

$\mathrm{A}=(\mathrm{V} 0.1, \mathrm{~L} 0.1 \mathrm{I} 0.1) ; \mathrm{B}=(\mathrm{V} 0.1, \mathrm{~L} 0.1, \mathrm{I} 0.2) ; \mathrm{C}=(\mathrm{V} 0.1, \mathrm{~L} 0.2) ; \mathrm{D}=(\mathrm{V} 0.1, \mathrm{~L} 0.2, \mathrm{I} 0.2) ; \mathrm{I} 0.1) ; \mathrm{E}=(\mathrm{V} 0.2, \mathrm{~L} 0.1, \mathrm{I} 0.1)$

$\mathrm{F}=(\mathrm{V} 0.2, \mathrm{~L} 0.1, \mathrm{I} 0.2) ; \mathrm{G}=(\mathrm{V} 0.2, \mathrm{~L} 0.2, \mathrm{I} 0.1) ; \mathrm{H}=(\mathrm{V} 0.2, \mathrm{~L} 0.2, \mathrm{I} 0.2) \mathrm{I}(\mathrm{control})=(\mathrm{V} 0.0, \mathrm{~L} 0.0, \mathrm{I} 0.0)$.

Values in same column with different superscripts indicates significantly different $(\mathrm{P}<0.05)$

Nutrition needed by protozoa is protein and fermentable energy in the form of starch or sugar, on the other hand corn cob contain carbohydrate mostly in the form of fiber this condition retarded the growth of protozoa. Mustofa et al. (2012) reported that fermentation of ammoniated $\mathrm{CC}$ which was processed using commercial starter produced $113 \mathrm{mM}$ VFA, increased cellulolytic microbial population increased VFA production as energy source for livestock. The amount of supply protein from microbial biomass into small intestine could be up to $50-80 \%$ from total absorbed protein (Bach et al. 2005). Treatment G (V 0.2 , L 0.2 , I 0.1) produced highest bacterial population among four BCAA combination. Fibrous fermented bacterial such as Ruminococcus albus, Ruminococcus flavefaciens, Fibrobacter succinogenes, and Butyrivibio fibrisolvents required branched-chain fatty acid (BCFA) such as isobutyric, isovaleric, valeric, and 2methylbutyric acids for their growth (Zhang et al. 2013). BCFA could be obtained from feed protein or recycled of rumen bacterial protein through oxidative deamination and decarboxylation from valin, leucin, and isoleucin (Moharrery 2004). The best BCAA combination in the present study was different to the study reported by Zain et al. (2008). 


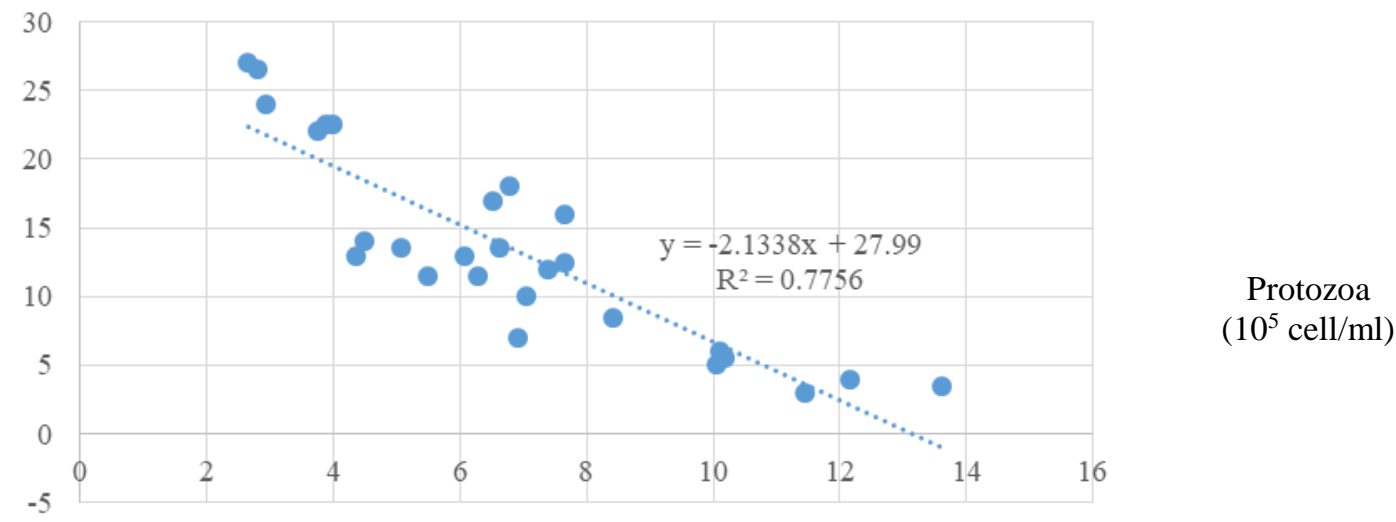

Bacterial population $\left(10^{\wedge} 9\right.$ colony $\left./ \mathrm{ml}\right)$

Figure 2. Corellation between bacteria and protozoa population in the in vitro rumen of amoniated CC supplemented with BCAA

They reported higher rumen bacterial population in sheep fed on palm press fiber complete diet supplementd with valin $0.1 \%$, leucin $0.15 \%$ dan isoleucin $0.2 \%$ than control diet $\left(18.88 \times 10^{10} \mathrm{col} / \mathrm{ml} v \mathrm{~s}\right.$ $\left.10.9 \times 10^{10} \mathrm{col} / \mathrm{ml}\right)$. The different results in the present study with Zain et al. (2008) study in term of bacterial population was due to the difference quality nutrient supply to support bacterial synthesis.

The used of BCAA in the field particularly for small holder farmers is quite expensive, this can be as constraint in the used of BCAA. Therefore it is needed to search alternative for BCAA sources which is cheap and easily obtained. Some of forage protein such as leucaena, gliricidia, calliandra and cassava leaves contain high BCAA. According to Hartadi et al. (1997) leucaena contained valin $1.51 \%$, leucin $2.33 \%$ and isoleucin $1.3 \%$. Widiawati et al. (2007) reported that leucaena contained valin $637 \mathrm{mg} / \mathrm{g} \mathrm{N}$, leucin $504 \mathrm{mg} / \mathrm{g}$ $\mathrm{N}$, isoleucin $536 \mathrm{mg} / \mathrm{g} \mathrm{N}$, Gliricidia maculate leaves contained valin $646 \mathrm{mg} / \mathrm{g} \mathrm{N}$, leucin $521 \mathrm{mg} / \mathrm{g} \mathrm{N}$, isoleucin $563 \mathrm{mg} / \mathrm{g} \mathrm{N}$. Caliandra leaves contained valin $685 \mathrm{mg} / \mathrm{g} \mathrm{N}$, leucin $543 \mathrm{mg} / \mathrm{g} \mathrm{N}$, isoleucin $564 \mathrm{mg} / \mathrm{g} \mathrm{N}$. Cassava leaves contained valin $1 \%$, leucin $1.3 \%$ and isoleucin $0.84 \%$ (Puastuti 2013, Unpublished). Therefore in field application utilization of BCAA can be implemented through forage protein source supplementation which is rich in amino acid with BCAA composition closed to treatment $\mathrm{G}$ (valin $0.2 \%$, leusin $0.2 \%$ dan isoleusin $0.1 \%$ ). However, attention need to be given type of legume forage source which will affect the composition of total ration and may have different effect, therefore further research on the use of forage as BCAA source need to be done.

\section{CONCLUSION}

Processing corn cob using urea treatment at 3\% DM of corn cob was able to increase CP content by $78 \%$. Supplemented ammoniated CC with molasses 5\% and BCAA combination with valin $0.2 \%$, leusin $0.2 \%$ dan isoleusin $0.1 \%$ resulted in highest $\mathrm{DM}, \mathrm{OM}$ and NDF diegestibility of $58.06 \%, 59.49 \%, 54.19 \%$ respectively as indicated by the highest bacterial population and the lowest protozoa population. The utilization of ammoniated $\mathrm{CC}$ is suggested supplemented by molases $5 \%$ and BCAA combination valin $0.2 \%$, leusin $0.2 \%$ dan isoleusin $0.1 \%$.

\section{ACKNOWLEDGEMENT}

Appreciation and thanks is address to Professor Budi Haryanto for his scientific advices in copletion of the experiment and te completion of this paper. Special thanks is also adressed to Mr. Maplani and Mr Suharto for their helps in carrying out the experiment.

\section{REFERENCES}

Adeniji AA. 2010. Effects of dietary grit inclusion on the utilization of rice rusk by pullet chicks. Trop Subtrop Agroecosyst. 12:175-180.

Al Qori'ah, Surono, Sutrisno. 2016. Sintesis protein mikroba dan aktivitas selulolitik akibat penambahan level zeolit sumber nitrogen slow release pada glukosa murni secara in vitro. Jurnal Ilmu-Ilmu Peternakan. 26:1-7. 
Alam MK, Ogata Y, Sato Y, Sano H. 2016. Effects of rice straw supplemented with urea and molasses on intermediary metabolism of plasma glucose and leucine in sheep. Asian Australas J Anim Sci. 29:523-529.

[AOAC] Association of Official Analytical Chemist. 1990. Association of Official Analytical Chemist, Official Method of Analysis. 12th ed. AOAC.

Bach A, Calsamiglia S, Stern MD. 2005. Nitrogen metabolism in the rumen. J Dairy Sci. 88:E9-E21.

Bata M. 2008. Pengaruh molases pada amoniasi jerami padi menggunakan urea terhadap kecernaan bahan kering dan bahan organik in vitro. Agripet. 8:15-20.

Blummel M, Steingass H, Becker K. 1997. The relationship between in vitro gas production, in vitromicrobial biomass yield and $15 \mathrm{~N}$ incorporation and itsimplications for the prediction of voluntary feed intake of roughages. Br J Nutr. 77:911-921.

Chumpawadee S, Sommart K, Vongpralub T, Pattarajinda V. 2006. Effects of synchronizing the rate of dietary energy and nitrogen release on ruminal fermentation, nitrogen and nutrient digestibility in beef cattle. Asian-Australas J Anim Sci. 19:181-188.

Clark JH, Klusmeyer TH, Cameron MR. 1992. Microbial protein synthesis and flows of nitrogen fractions to the duodenum of dairy cows. J Dairy Sci. 75:2304-2323.

Dean DB, Adesogan AT, Krueger NA, Little RC. 2008. Effect of treatment with ammonia or fibrolytic enzymes on chemical composition and ruminal degradability of hays produces from tropical grasses. Anim Feed Sci Technol. 145:68-83

Febrina D. 2012. Kecernaan ransum sapi Peranakan Ongole berbasis limbah perkebunan kelapa sawit yang diamoniasi urea. Jurnal Peternakan. 9:68-74.

Gunun P, Wanapat M, Anantasook N. 2013. Effects of physical form and urea treatment of rice straw on rumen fermentation, microbial protein synthesis and nutrient digestibility in dairy steers. Asian-Australas J Anim Sci. 26:1689-1697.

Hartadi H, Reksohadiprodjo S, Tillman AD. 1997. Tabel komposisi pakan untuk Indonesia. Cetakan Kedua. Yogyakarta (Indones): Gadjah Mada University Press.

Hastuti D, Shofia Nur A, Iskandar Muda B. 2011. Pengaruh perlakuan teknologi amofer (amoniasi fermentasi) pada limbah tongkol jagung sebagai alternatif pakan berkualitas ternak ruminansia. Mediagro. 7:55-65.

Hailu A, Melaku S, Tamir B, Tassew A. 2011. Body weight and carcass characteristics of Washera sheep fed urea treated rice straw supplemented with graded levels of concentrate mix. Livest Res Rural Develop. Vol. 23 Article 164. http://www.lrrd.org/lrrd23/8/hail23164. htm.

Huyen NT, Wanapat M, Navanukraw C. 2012. Effect of mulberry leaf pellet (MUP) supplementation on rumen fermentation and nutrient digestibility in beef cattle fed on rice straw-based diets. Anim. Feed Sci. Technol. 175:8-15.

Khejornsart P, Wanapat M. 2010. Effect of chemical treatment of rice straw on rumen fermentation characteristic, anaerobic fungal diversity in vitro. J Anim Vet Adv. 9:3070-3076.

Laconi EB, Jayanegara A. 2015. Improving nutritional quality of cocoa pod (Theobroma cacao) through chemical and biological treatments for ruminant feeding: In vitro and in vivo evaluation. Asian-Australas $\mathbf{J}$ Anim Sci. 28:343-350.

Mapato C, Wanapat M, Cherdthong A. 2010. Effect of urea treatment of straw and dietary level of vegetable oil on lactating dairy cows. Trop Anim Health Prod. 42:16351642 .

McAllen AB, Smith RH. 1983. Factor influencing the digestion of dietary carbohydrat between the mouth and abomasum of steers. Br J Nutr. 50:445.

Menke KH, Steingass H. 1988. Estimation of the energetic feed value obtained from chemical analysis and in vitro gas production using rumen fluid. Anim Res Dev. 28:755.

Moharrery A. 2004. Effect of isoacids on some rumen enzymes. J Anim Feed Sci. 13:159-162.

Mustofa Z, Tampoebolon BIM; Subrata A. 2012. Peningkatan kualitas tongkol jagung teramoniasi melalui teknologi fermentasi menggunakan starter komersial terhadap produksi VFA dan NH3 rumen secara in vitro. Anim Agric J. 1:599-609.

Nurfeta A, Tolera A, Eik LO, Sundstol F. 2008. Feeding value of enset (Ensete ventricosum), Desmodium intortum hay and untreated or urea and calsium oxide treated wheat straw for sheep. J Anim Physiol Anim Nutr 93:94-104.

Nurhaita, Ningrat RWS. 2011. Efek suplementasi daun ubi kayu terhadap kecernaan daun sawit amoniasi secara in vitro. Jurnal Peternakan Indones. 13:43-47.

Nurhaita N, Jamarun L, Warly, Zain M. 2010. Kecernaan ransum domba berbasis daun sawit teramoniasi yang disuplementasi sulfur, fosfor, dan daun ubi kayu. Media Peternakan, 2010:144-149.

Nurhaita, Ruswendi, R Wismalinda, Robiyanto. 2014. Optimizing rumen bioprocess through supplementation of microbe precursor nutrient in ammoniation of palm oil frond-base cattle ration. J Adv Agric Technol. 1:1013 .

Ogimoto K, Imai S. 1981. Atlas of rumen microbiology. JSSP. Tokyo.

Oji UI, Etim HE, Okoye FC. 2007. Effects of urea and aqueous ammonia treatment on the composition and nutritive value of maize residues. Small Rumin Res. 69:232-236

Pathak AK. 2008. Various factors affecting microbial protein synthesis in the rumen. Vet World. 1:186-189. 
Prastyawan RM, Tampoebolon BIM, Surono. 2012. Peningkatan kualitas tongkol jagung melalui teknologi amoniasi fermentasi (amofer) terhadap kecernaan bahan kering dan bahan organik serta protein total secara in vitro. Anim Agric J. 1:611-621.

Puastuti W, Yulistiani D, Mathius IW, Giyai F, Dihansih E. 2010. Ransum berbasis kulit buah kakao yang disuplementasi Zn organik: Respon pertumbuhan pada domba. JITV. 16:269-277.

Puastuti W. 2009. Manipulasi bioproses dalam rumen untuk meningkatkan penggunaan pakan berserat. Wartazoa. 19:180-190.

Ramirez GR, Aguilera-Gonzalez JC, Garcia-Diaz G, NunezGonzalez AM. 2007. Effect of urea treatment on chemical composition and digestion of Cenchrus ciliaris and Cynodon dactylon hays and Zea mays residues. J Anim Vet Adv. 6:1036-1041.

SAS Institute. 2002. The SAS System for Windows. Release Version 9.0. Cary. NC (USA): SAS Inst.

Santoso B, Hariadi BTj, Manik H, Abubakar H. 2009. Kualitas rumput unggul tropika hasil ensilase dengan bakteri asam laktat dari ekstrak rumput terfermentasi. Media Peternakan. 32:137-144.

Satter LD, Slyter LL. 1974. Effect of ammonia concentration of rumen microbial protein production in vitro. $\mathrm{Br} \mathrm{J}$ Nutr. 32:199-208.

Scholljegerdes EJ, Weston TR, Ludden PA, Hess BW. 2005. Supplementing a ruminally undegradable protein supplement to maintain essential amino acid supply to the small intestine when forage intake is restricted in beef cattle. J Anim Sci. 83:2151-2161.

Setyadi JH, Tri Rahardjo, Suparwi. 2013. Kecernaan bahan kering dan bahan organik tongkol jagung (Zea mays) yang difermentasi dengan aspergillus niger secara in vitro. Jurnal Ilmiah Peternakan. 1:170-175.

Sumarsih S, Sutrisno CI, Pangestu E. 2007. Kualitas nutrisi dan kecernaan daun eceng gondok amoniasi yang difermentasi dengan Trichoderma viride pada berbagai lama pemeraman secara in vitro. J Indones Trop Anim Agric. 32:257-261.

Tedeschi LO, Fox DG, Fonseca MA, Francis L, Cavalcanti L. 2015. Models of protein and amino acid requirements for cattle: Invited Riview. R Bras Zootec. 44:109-132.

Ubwa ST, Abah J, Oshidi BA, Otokpa E. 2014. Studies on urea treated rice milling waste and its application as animal feed. Afr J Pure Appl Chem. 8:23-31.

Van Soest PJ. 2006. Rice straw the role of silica and treatment to improve quality. J Anim Feed Sci Technol. 130:137171.
Van Soest PJ, Robertson JB, Lewis BA. 1991. Methods for dietary fiber, neutral detergent fiber and non-starch polysaccharides in relation to animal nutrition. J Dairy Sci. 74:3583-3593.

Volden H. 1999. Effects of level of feeding and ruminally undegraded protein on ruminal bacterial protein synthesis, escape of dietary protein intestinal amino acid profile, and performance of dairy cows. J Anim Sci. 77:1905-1918.

Wanapat M, Polyrach S, Boonnop K, Mapato C, Cherdthong A. 2009. Effect of treating rice straw with urea and calcium hydroxide upon intake, digestibility, rumen fermentation and milk yield of dairy cows. Livest Sci. 125:238-243.

Widiawati Y. 2002. The utilisation of shrub legumes: Leucaena leucocephala, Gliricidia sepium and Calliandra callothyrsus for growing sheep (Thesis). Townsville (Australia): James Cook University.

Yadete GK. 2014. Effect wheat straw urea treatment and Leucaena leucochepala foliage hay supplementation on intake, digestibility, nitrogen balance and growth of lambs. Int J Livest Prod. 6:88-96.

Yalchi T, Afzalzade A, Sharifi RS. 2009. Effects of liquid ammonia and urea treatment on chemical composition and in vitro digestibility of triticale straw. J Anim Vet Adv. 8:1916-1920.

Yulistiani D, Puastuti W, Wina E, Supriati. 2012. Pengaruh berbagai pengolahan terhadap nilai nutrisi tongkol jagung: Komposisi kimia dan kecernaan in vitro. JITV. 17:59-66.

Zain M. 2007. Optimalisasi penggunaan serat sawit sebagai pakan serat alternatif dengan suplementasi daun ubi kayu dalam ransum ruminansia. J Indones Trop Anim Agric. 32:100-105.

Zain M, Jamarun N, Nurhaita. 2010. Effect of sulfur suplementation on in vitro fermentability and degradability of ammoniated rice straw. Pak J Nutr. 9:413-415.

Zain M, Sutardi T, Suryahadi; Ramli N. 2008. Effect of defaunation and supplementation methionine hydroxy analogue and branched chain amino acid in growing sheep diet based on palm press fiber ammoniated. Pak $\mathbf{J}$ Nutr. 7:813-816.

Zhang HL, Chen Y, Xu XL, Yang YX. 2013. Effects of Branched-chain Amino Acids on In vitro Ruminal Fermentation of Wheat Straw. Asian-Aust J Anim Sci. 26:523-528. 